\title{
Teaching Art Using Technology: The Views of High School Students in Greece
}

\author{
Kampouropoulou Maria, Lecturer \\ University of the Aegean, Department of Primary Education \\ Rhodes, Greece \\ Tel: 30-2241-022-229 E-mail: kampour@rhodes.aegean.gr \\ Fokiali Persa, Assoc. Prof. \\ University of the Aegean, Department of Pre-school Education and Educational Design \\ Rhodes, Greece \\ Tel: 30-2241-099-148Ｅ-mail: persa@rhodes.aegean.gr \\ Athanasiadis Ilias (Corresponding author), Assoc. Prof. \\ University of the Aegean, Department of Primary Education \\ Rhodes, Greece \\ Tel: 30-2241-022-947Ｅ-mail: athanasilias@gmail.com \\ Stefos Efstathios, $\mathrm{PhD}$ Candidate \\ University of the Aegean, Department of Primary Education \\ Rhodes, Greece \\ Tel: 30-2241-094-522 E-mail: estefos@otenet.gr
}

Received: July 19, 2011

doi:10.5539/res.v3n2p98
Accepted: August 25, $2011 \quad$ Published: December 1, 2011

URL: http://dx.doi.org/10.5539/res.v3n2p98

\begin{abstract}
In this article we present the results of a survey, which studied the views of 21,040 high school students from all around Greece, regarding the assessment of Information and Communication Technologies (ICT) in the teaching of Art. The results were processed using Multidimensional Statistic Data Analysis, on the axis of dividing the students' sample in 5 groups, in regard to their positive or negative views on using Technology in Art. Besides the fact that the vast majority of the student sample (87.04\%) appears to be familiar with ICT, there was a differentiation in answers among the student groups. It is especially interesting that in questions regarding the influence of Technology on modern Art and the consequent appearance of new Art forms, $50.00 \%$ and $65.59 \%$ of the students, respectively, gave positive answers. In general, the survey's results confirmed the hypothesis of a positive attitude of students towards using Technology in Art education.
\end{abstract}

Keywords: Art, Technology, Art education, New art forms

\section{Introduction}

Although Art and Technology might be considered incompatible, they are deeply interwoven, even etymologically: techno-logy is literally the speech (logos) about Art (techni). They share an interactive and multidimensional relationship. From prehistoric times, up to today, Art has been using materials created by Technology, as its basic structural means of expression, while at the same time, Technology has often been the subject and the reference point for Art, as artists depict their time's Technology, declaring their experimentation with new means, many decades before the digital revolution. Of course, this relationship is more than prominent 
today, as ICT promotes the artistic character of multimedia and transmedia applications, creates new types of Art (computer Art, animation, Internet Art, cyber Art, etc.) and makes the boundaries between Art and technological application more and more indistinguishable (Grau 2003; Chesher, 2004). The use of New Technologies in Art teaching leads to the creation of new learning environments that motivate the students in a positive way (Ames, 1992; Pintrich and Schunk, 2002).

The above findings are definitely true for the field of education too, especially the socio-cultural context of teaching Art, which is rapidly shifting, in Greece and worldwide. Technology is prominent in all levels of teaching practice (teaching about Technology, teaching integrating Technology, teaching facilitated by Technology) (Vannatta et al. 2001), and functions as a catalyst for the new developments in education, positioning Art education in the post-modern context of an ever changing world (Boughton et al. 1996).

In regard to the use of ICT in Art education, many teaching approaches have been proposed. Within most of those, internet can be used: as a source of educational material, as a means for the development of creativity and self expression, in order to learn about new Art forms and also as a field of conversation and communication on the images of the digital world and the visual civilization (Sweeny, 2004). Digital Art activities are introduced in many curricula in order to a) attract students who might think they have no artistic talent and consequently show little interest in Arts (King 2001; Roland, 1994), and b) the natural and appealing familiarization of students with the use of PCs, while at the same time opening up their artistic ways of expression (Carpenter and Taylor, 2003; Tavin, 2002).

The levels of ICT integration in education (promotion of active learning, research of complex problems, demonstration of practical implementation of Computer Technology and assessing the students' interest) have been studied in the context of various researches, which were mainly conducted in America and Europe (in Greece, too, during the last decade). Through the experience of applying ICT in the field of education, so far, one can notice a more positive attitude of students towards knowledge and a "motivation" which eventually contributes to the improvement of their performances. The assessment of relevant learning environments by those who participate in the education practice has also been extensively used in educational research. Thus, the teachers' views have been studied, in regard to: a) their role in the education practice, b) their success in using Technology, and c) the role of Technology in education (Honey and Moeler, 1990; Chen, 2001).

However, the students' own views in regard to their learning environment are more important factors than the educators' assessments, who tend to paint a more positive picture than their students for their practices (Fraser, 1998).

Given the lack of similar researches, in regard to the integration of ICT in the field of Art education, the present survey was designed and implemented, aiming to explore the students' views on the use of Technology in Art teaching. On the base of the hypothesis that students are positive towards integrating ICT in Art education and at the same time, familiar with new technologies, the participants were asked to answer questions on their familiarity with personal computers, the influence of Technology on Art, the use of new media from artists and the role of Technology in the creation of new Art forms.

\section{The Survey}

The survey took place during the academic year 2010-2011. Students of second and third High School grades from all around Greece participated in the survey and answered a questionnaire in order to have their views researched in regard to the use of Technology in Art. In the frame of the survey the significant research question about the Greek students' views towards the use of ICT in Art education has been developed. In order to extract the survey's results, we used statistics software SPSS v.17 and SPAD v.4.5, offered by the Department of Primary Education in the University of the Aegean.

\section{The students' views in regard to the use of Technology in Art}

21,040 High School students took part in the survey. $49.60 \%$ of them were boys and $50.40 \%$ were girls.

[Insert Table 1 here]

[Insert Figure 1 here]

$18.19 \%$ of the students attended schools in areas populated with up to 5,000 residents, $12.89 \%$ of them schools in areas populated with 5,001 to 10,000 residents, $22.28 \%$ schools in areas with 10,001 to 30,000 residents, $15.51 \%$ schools in areas with 30,001 to 50,000 residents, $17.38 \%$ schools in areas with 50,001 to 100,000 residents, and $13.75 \%$ schools in areas with more than 100,001 residents.

[Insert Table 2 here] 
[Insert Figure 2 here]

When asked "Which class of High school do you attend?", 1.64\% didn't answer. Of those who answered, 49.52\% were in the $2^{\text {nd }}$ grade and $50.48 \%$ in $3^{\text {rd }}$.

[Insert Table 3 here]

[Insert Figure 3 here]

When asked “Are you interested in Arts?", 7.18\% didn't answer. Of the students who did answer, $56.79 \%$ said they are interested in Arts and $43.03 \%$ that they are not.

[Insert Table 4 here]

[Insert Figure 4 here]

$87.04 \%$ of the students who participated in the survey, declared they know how to use a computer to change colors, $74.64 \%$ that they know how to use a computer in order to change shapes, $56.79 \%$ that they know how to use a computer in order to add shapes and make new combinations, 50.74\% that they know how to use a computer in order to subtract details and create abstract designs, $78.95 \%$ that they know how to zoom in details, $40.81 \%$ that they can multiply designs or details and create patterns, $61.20 \%$ that they know how to use a computer in order to make combinations of paintings and pictures and $37.91 \%$ that they know how to use a computer in order to print what they've created quickly and on various materials (paper, textile, canvas etc.).

[Insert Table 5 here]

[Insert Figure 5 here]

When asked "Is Art influenced by Technology today?", 3.70\% of the students who participated didn't answer. Of those who answered, $8.40 \%$ stated that they completely disagree, $10.84 \%$ that they disagree, $30.76 \%$ that they neither agree or disagree, $32.83 \%$ of the students agreed and $17.17 \%$ said that they strongly agree. It is interesting that $50.00 \%$ of the participating students think that Art today is indeed influenced by Technology.

[Insert Table 6 here]

[Insert Figure 6 here]

The question "Is it good for a modern artist to use the tools of Technology when creating a project?" was not answered by $2.96 \%$ of the students. Of those who answered, $10.33 \%$ said they strongly disagree, $12.45 \%$ that they disagree, 36.97 that they neither agree nor disagree, $26.52 \%$ that they agree and $13.73 \%$ that they strongly agree. It is interesting to note that $40.25 \%$ of the students who took part in the survey believe it is good for a modern artist to use Technology tools when creating a project.

[Insert Table 7 here]

[Insert Figure 7 here]

When asked "Has Technology helped in the creation of new Art forms?", 4.77\% of the students who took part in the survey didn't answer. Of those who did, 7.29\% answered they strongly disagree, $7.03 \%$ that they disagree, $20.09 \%$ that they neither agree nor disagree, $37.11 \%$ that they agree and $28.48 \%$ that they strongly agree. It is important that $65.59 \%$ of the students who participated in the survey believe that Technology has helped create new Art forms, in contrast to the $14.32 \%$ who have the opposite opinion.

[Insert Table 8 here]

[Insert Figure 8 here]

\section{The results of the Multidimensional Analysis}

We will now present the analysis of the questionnaire that was made using Multidimensional Statistic Data Analysis, which allows for the sketching of the students' differentiation criteria and for their classification into groups according to the common answers they have provided in the total of the questionnaires (Benzécri, 1992). Thus we can examine the result of all the answers interrelation and will see that what plays a major role is not the frequency of the emergence of a characteristic but the combination of many characteristics at the same time, something that leads to the emergence of classification criteria, or a series of typologies.

The methods that were used are Multiple Correspondence Factor Analysis, which defines the students' differentiation criteria and Hierarchical Clustering, which leads to the formation of groups/clusters according to common answers and common characteristics among the students that took part in the survey (Athanasiadis, 1995). 


\subsection{Students' differentiation criteria}

In order to discover which way were the students that participated differentiated, depending on all of their answers, we used the Multiple Correspondence analysis method, which is based on the correlation of all the variables at the same time. The results of this analysis set the factorial axes, which at the same time are the students' differentiation criteria. These criteria are expressed as oppositions in their answers, their way of answering and the way their characteristics are recorded. These criteria correspond to the axes of Correspondence Analysis which are presented in order of significance (Martin, 2008). The elements that differentiate the 21,040 students that participated in the survey are defined by three criteria of differentiation, the three factor axes that follow.

$1^{\text {st }}$ differentiation criterion ( $1^{\text {st }}$ factor axis - inertia percentage 6.13\%): The use of Technology in Art

The 1st differentiation criterion is consisted on one hand of students who know how to use a computer to change colors, zoom in details and change shapes and make new combinations, know the technique of collage, believe that Art offers them entertainment and will help them find a personal leisure pursuit. These students believe that Technology contributes in the creation of new Art forms, as well as helping the artist to finish a project faster, and they stated that Technology brings Art and people closer together and that Art is influenced by Technology and can help in product design as well as in the development of aesthetic standards. On the other hand, there are students who don't know how to use a computer to change colors, zoom into details or change shapes and make new combinations and don't know how to make a collage. These students don't believe that Art will help them find a personal leisure pursuit and declared that Technology will not help them in their studies, nor in their professional and everyday life.

$2^{\text {nd }}$ differentiation criterion $\left(2^{\text {nd }}\right.$ factor axis - inertia percentage $3.68 \%$ ): The interest in Art

In the second differentiation criterion, there are students who are interested in Arts that would like to spend some time in school creating art projects with the aid of New Technologies and when they are engaged in art projects they feel that their imagination and creativity is enhanced. These students know how to use a computer to change and add shapes, know how to combine paintings with pictures and believe that they are interested in and entertained by Art. On the other hand, there are students who are not interested in arts and when occupied with art projects they don't feel their imagination and creativity are in any way enhanced. They would not like to spend time in school creating art projects using New Technologies and don't believe Art can offer them entertainment. These students stated that they are not interested in Art, it should not be taught to all ages and that Technology has not helped to create new Art forms.

$3^{\text {rd }}$ differentiation criterion $\left(3^{\text {rd }}\right.$ factor axis - inertia percentage 3.07\%): The connection between Art and Technology

In the third, in order of significance, differentiation criterion, on one hand there are students who, when engaged in Art, do not feel their imagination and creativity are being enhanced, declared that Art does not offer entertainment and does not help them develop aesthetic standards. These students do not believe that Technology has helped create new Art forms, nor that it helps artists finish a project faster, and said that they know how to use a computer to multiply patterns, subtract details, add shapes and make new combinations. On the other hand, there are students who said that Art offers them entertainment, believe that Technology helped create new Art forms, feel their imagination and creativity are developed when they are engaged in Art projects, and stated that Art helps product design. These students know how to use a computer to multiply designs, create patterns and print out quickly and on various materials.

\subsection{Results of the hierarchical classification}

Looking for a classification of the students' views on the use of New Technologies in Art education we implemented the method of Hierarchical Classification. This approach offers the advantage of representing the centers of teams on the factor levels, while at the same time presenting the groups of answers to the initial questions, aiming to a more complete interpretation of the differences between the groups. The Hierarchical Clustering led to the formation of five groups of students, which are disposed according to Figure 9. Next to each group you see the number and the percentage of the students that constitute it.

[Insert Figure 9 here]

$1^{\text {st }}$ group (7,749 students, $36.83 \%$ of the sample)

The $1^{\text {st }}$ group consists of students for whom Art is a means of entertainment, who feel that their imagination and creativity are enhanced when they are engaged in Art projects and believe that they are interested in Art, it relaxes 
them and helps them develop aesthetic standards. These students said that Technology makes Art more accessible to people and that they know how to use a computer to change shapes and zoom in details.

$2^{\text {nd }}$ group (4,894 students, $23.26 \%$ of the sample)

The $2^{\text {nd }}$ group consists of students who are interested in Arts and believe that Art should be taught in all education grades, they declared that modern people should have basic Art knowledge and that they have sufficient art knowledge for their own age. These students would like to be engaged in Art projects with the aid of New Technologies at school and believe that Art will help them in their studies as well as their career.

$3^{\text {rd }}$ group (6,952 students, $33.04 \%$ of the sample)

The $3^{\text {rd }}$ group is constituted of students who are not interested in Arts, would not like to be engaged in art projects with the aid of New Technologies at school, do not feel their imagination and creativity are enhanced through Art and do not believe that Art can help them develop aesthetic standards. These students said they are not interested in Art and do not know how to use a computer to change color and shapes.

$4^{\text {th }}$ group ( 1,023 students, $4.86 \%$ of the sample)

The $4^{\text {th }}$ group consists of students who are not interested in, nor relaxed by, Art, do not believe that Art can help in product design nor that modern people should have basic knowledge on Art. These students said that Technology has not helped create new Art forms, believe that Art today is not influenced by Technology and that Technology does not help artists finish a project faster.

$5^{\text {th }}$ group (423 students, $2.02 \%$ of the sample)

The $5^{\text {th }}$ group consists of students who believe that Technology will not help them in their studies, nor in their professional and everyday life and said that Art might help them find a personal leisure pastime. These students do not know how to use a computer to change colors and shapes, zoom in details, add shapes and make new combinations.

The first and second groups, which are consisted of students positive towards using Technology in Art, differentiate in regard to other groups, members of which were negative towards the use of Technology in Arts. These differentiations are depicted in Figure 10, Correspondence Analysis (Factor Level 1x2), where the centroids of the five teams are presented on the level of the first two axes. The relevant position of the teams in regard to the two axes and especially their intersection showcases the contradictions and the similarities of the characteristics demonstrated by students of each team.

[Insert Figure 10 here]

\section{Conclusions}

The research question about the Greek students' views towards the use of ICT in Art education has been answered positively by the majority of the students that participated in the survey. Students like to use the New Technologies in a modern educational environment which offers them the important component of motivation to learn (Hakkerainen et al, 2007; Sanders and Morrison-Shetlar, 2001). Technology improves the quality of the learning experience.

The continuously increasing use of new information and communication technologies in almost all the spectrum of human activity signals the approach of a new era, the main characteristic of which is the need to use information and refresh knowledge very rapidly. Our views on Art and its teaching cannot remain the same in the era of Internet. In this frame, the tools that the Art teacher uses must be the appropriate; they should provide students with useful information in an understandably engaging and accessible way (Bangery, 2004). As it is in its most mature level, in its relationship with Technology, web Art powerfully poses the question of the relationship between Art and Technology and promotes, in a most revolutionary way, the cultural dimension of education (Anderson et al., 2001).

In this context, the assessment of the present survey's results aims to suggest proposals which will contribute to the upgrading of the dialogue between ICT and Art education and the prospect of their creative co-existence in modern school.

The supply of interactive whiteboards in the Greek High schools that started in the school year 2010 - 2011 gives a new interest in the survey about the use of New Technologies in Art teaching. The new applications, the acceptance by the educational community, the appropriate training of the Art teachers, the effectiveness of the new methods in everyday teaching practice, the technical and operational problems that will arise, etc. constitute 
a major challenge for the researchers who will seek to continue studying and to go beyond the results of this paper on the use of New Technologies in Art teaching (Athanasiadis et al, 2010).

\section{References}

Ames, C. (1992). Classrooms: Goals, structures, and student motivation. Journal of Educational Psychology, 84, 261-271. http://dx.doi.org/10.1037/0022-0663.84.3.261

Anderson, T., Rourke, L., Garrison, R. and Archer, W. (2001). Assessing teaching presence in a computer conferencing context. Journal of Asynchronous Learning Networks, 5(2). [Online] Available: http://www.sloan-c.org/publications/jaln/v5n2/pdf/v5n2_anderson.pdf

Athanasiadis, I., Stefos, E., Gialamas, V. and Tsolakidis, K. (2010). New Technologies and the Project Method in Teaching Statistics: A case study in Higher Education. In the Proceedings of the $27^{\text {th }}$ Panhellenic Conference of Mathematical Education. 243-252. Halkida.

Athanasiadis, I. (1995). Correspondence Analysis and Hierarchical Classification. New Technologies Editions, $51-56$.

Bangery, A. W. (2004). The Seven Priniciples of Good Practice: A framework for evaluating online teaching. Internet and Higher Education, 7(3), 217-232. http://dx.doi.org/10.1016/j.iheduc.2004.06.003

Benzécri, P. (1992). Correspondence Analysis Handbook. New York: Dekker.

Boughton, D., Eisner, E. and Ligtvoet, J. (1996). Evaluating and assessing the visual arts in education: International perspectives. New York: Teachers College Press at Columbia University.

British Educational Communications and Technology Agency. (2004). A review of the research literature on barriers to the uptake of ICT by teachers. [Online] Available: http://www.becta.org.uk/ page_documents/research/barriers.pdf

Carpenter, B. S. and Taylor, P. G. (2003). Racing Thoughts: Altering Our Ways of Knowing and Being Through Computer Hypertext. Studies in Art Education, 45(1), 40-55.

Chapman, L. (1978). Approaches to Art in Education. New York: Harcourt Brace.

Chen, Y. (2001). Teachers' attitude and anxiety toward computer use in classrooms and the implication for teacher education. [Online] Available: http://www.mste.uiuc.edu/courses/ ci407su01/students/south/ychen17/ termproject/WP2.htm

Chesher, C. (2004). How to tell apart video games and new media art. In Interaction Systems, Theory and Practice, Creativity and Cognition Conference, Studios Press, Sydney, 225-227.

Fraser, B. J. (1998). Classroom environment instruments: Development, validity, and applications. Learning Environments Research, 1, 7-33. http://dx.doi.org/10.1023/A:1009932514731

Grau, O. (2003). Virtual Art: From Illusion to Immersion. The MIT Press, Cambridge, Massachusetts.

Hakkarainen, P., Saarelainen T. and Ruokamo H. (2007). Towards meaningful learning through digital video supported, case based teaching. Australasian Journal of Educational Technology 2007, 23(1), 87-109.

Honey, M. and Moeller, B. (1990). Teachers' beliefs and technology integration: Different values, different understandings. Tech. Rep. No. 6. Washington, DC: Office of Educational Research and Improvement, U.S. Department of Education. (ERIC Document Reproduction Service No. ED 326 203) [Online] Abstract Available: http://www.edrs.com/Webstore/Detail.CFM?Ednumber=ED326203

Kazu, I. Y. and Yavulzalp, N. (2008). An analysis of the primary school teachers' usage of instructional software. International Journal of Emerging Technologies, 3 (1), 45-53.

Kennewell, S. and Morgan, A. (2003). Student teachers' experiences and attitudes towards using interactive whiteboards in the teaching and learning of young children. In the Proceedings of the IFIP Working Groups 3.5 Conference: Young Children and Learning Technologies. UWS Parramatta. [Online] Available: http://crpit.com/confpapers/CRPITV34Kennewell1.pdf

King, A. (2001). Excerpts from the Sketchstacks Curriculum Literature Review: A New Vocabulary for New Media. [Online] Available: http://www.pixelpixie.net/litreview.html

Martin, O. (2008). The analysis of quantitative data, Transl. Athanasiadis, I. pp.86-88. Athens: Topos

Pintrich, P. R. and Schunk, D. H. (2002). Motivation in education: Theory, research, and Applications (2 ${ }^{\text {nd }}$ Ed.).

Columbus, OH: Merrill-Prentice Hall. 
Roland, C. (1994). Preparing Children for the Twenty-First Century: A Rationale for Integrating New Technology into School Arts Programs. [Online] Available: http://grove.ufl.edu/ rolandc/arts technology.html

Sanders, D. W. and Morrison-Shetlar, A. I. (2001). Student Attitudes toward Web-Enhanced Instruction in an Introductory Biology Course. Journal of Research on computing in Education, 33(3), 251-262.

Sweeny, R. W. (2004). Lines of Sight in the 'Network Society': Simulation Art Education and a Digital Culture. Studies in Art Education, Fall. [Online] Available: www.findartcles.com

Tavin, K. (2002). Engaging advertisements: Looking for meaning in and through art education. Visual Arts Research, 28(2), 38-47.

Vannatta, R., Beyerbach, B. and Walsh, C. (2001). From Teaching Technology to Using Technology to Enhance Student Learning: Preservice Teachers' Changing Perceptions of Technology Infusion. Journal of Technology and Teacher Education, 9(1), 105-127. Norfolk, VA: AACE. [Online] Available: http://www.editlib.org/p/8456

Table 1. Sex

\begin{tabular}{|l|c|c|}
\hline & $\mathrm{n}$ & $\%$ \\
\hline Boy & 10,436 & $49.60 \%$ \\
\hline Girl & 10,604 & $50.40 \%$ \\
\hline Total & 21,040 & $100.00 \%$ \\
\hline
\end{tabular}

Table 2. Population of the region where the school is located

\begin{tabular}{|l|c|c|}
\hline & $\mathrm{n}$ & $\%$ \\
\hline Up to 5,000 residents & 3,827 & $18.19 \%$ \\
\hline $5,001-10,000$ residents & 2,713 & $12.89 \%$ \\
\hline $10,001-30,000$ residents & 4,687 & $22.28 \%$ \\
\hline $30,001-50,000$ residents & 3,263 & $15.51 \%$ \\
\hline $50,001-100,000$ residents & 3,657 & $17.38 \%$ \\
\hline$>100,000$ residents & 2,893 & $13.75 \%$ \\
\hline Total & 21,040 & $100.00 \%$ \\
\hline
\end{tabular}

Table 3. Which class of the High school do you attend?

\begin{tabular}{|l|c|c|}
\hline & $\mathrm{n}$ & $\%$ \\
\hline Second class & 10,249 & $49.52 \%$ \\
\hline Third class & 10,446 & $50.48 \%$ \\
\hline Total & 20,695 & $100.00 \%$ \\
\hline
\end{tabular}


Table 4. Are you interested in Arts?

\begin{tabular}{|l|c|c|}
\hline & $\mathrm{n}$ & $\%$ \\
\hline Yes & 11,126 & $56.97 \%$ \\
\hline No & 8,403 & $43.03 \%$ \\
\hline Total & 19,529 & $100.00 \%$ \\
\hline
\end{tabular}

Table 5. You know how to use the computer to...

\begin{tabular}{|l|c|c|}
\hline \multicolumn{1}{|c|}{} & $\mathrm{n}$ & $\%$ \\
\hline change the colors? & 18,313 & $87.04 \%$ \\
\hline change the shapes? & 15,704 & $76.64 \%$ \\
\hline add shapes and make new combinations? & 11,948 & $56.79 \%$ \\
\hline subtract details and make abstract patterns? & 10,675 & $50.74 \%$ \\
\hline zoom into the details? & 16,612 & $78.95 \%$ \\
\hline multiply designs or details and create patterns? & 8,586 & $40.81 \%$ \\
\hline make combinations of paintings and pictures? & 12,877 & $61.20 \%$ \\
\hline $\begin{array}{l}\text { print out very quickly and in different materials what } \\
\text { you've done? }\end{array}$ & 7.977 & $37.91 \%$ \\
\hline
\end{tabular}

Table 6. Is Art influenced by Technology today?

\begin{tabular}{|l|c|c|}
\hline & $\mathrm{n}$ & $\%$ \\
\hline Strongly disagree & 1,701 & $8.40 \%$ \\
\hline Disagree & 2,197 & $10.84 \%$ \\
\hline Neither agree nor disagree & 6,233 & $30.76 \%$ \\
\hline Agree & 6,653 & $32.83 \%$ \\
\hline Strongly agree & 3,478 & $17.17 \%$ \\
\hline Total & 20,262 & $100.00 \%$ \\
\hline
\end{tabular}

Table 7. Is it good for a modern artist to use the tools of Technology when creating a project?

\begin{tabular}{|l|c|c|}
\hline & $\mathrm{n}$ & $\%$ \\
\hline Strongly disagree & 2,110 & $10.33 \%$ \\
\hline Disagree & 2,543 & $12.45 \%$ \\
\hline Neither agree nor disagree & 7,548 & $36.97 \%$ \\
\hline Agree & 5,414 & $26.52 \%$ \\
\hline Strongly agree & 2,803 & $13.73 \%$ \\
\hline Total & 20,418 & $100.00 \%$ \\
\hline
\end{tabular}


Table 8. Has Technology helped in the creation of new forms of Art?

\begin{tabular}{|l|c|c|}
\hline & $\mathrm{n}$ & $\%$ \\
\hline Strongly disagree & 1,460 & $7.29 \%$ \\
\hline Disagree & 1,409 & $7.03 \%$ \\
\hline Neither agree nor disagree & 4,025 & $20.09 \%$ \\
\hline Agree & 7,435 & $37.11 \%$ \\
\hline Strongly agree & 5,707 & $28.48 \%$ \\
\hline Total & 20,036 & $100.00 \%$ \\
\hline
\end{tabular}

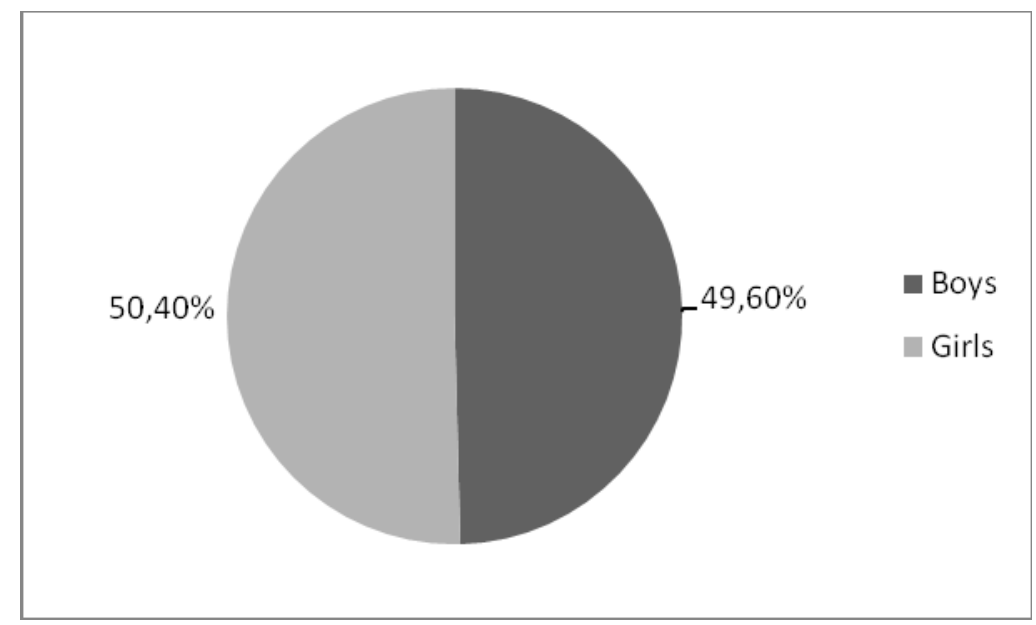

Figure 1. Sex

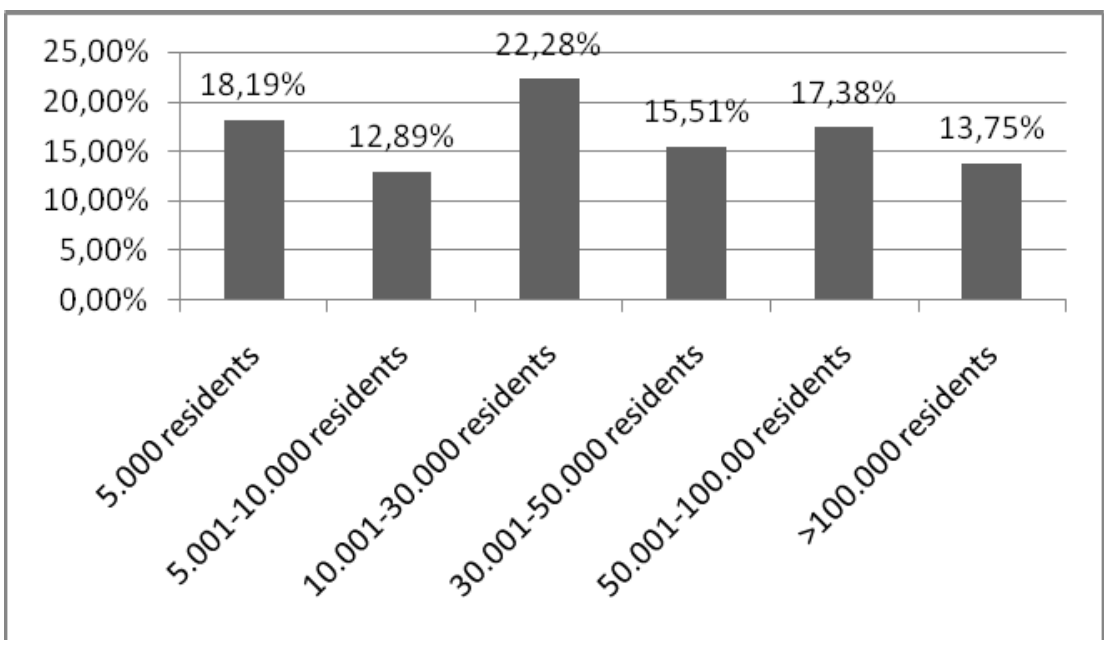

Figure 2. Population of The Region Where the School Is Located 


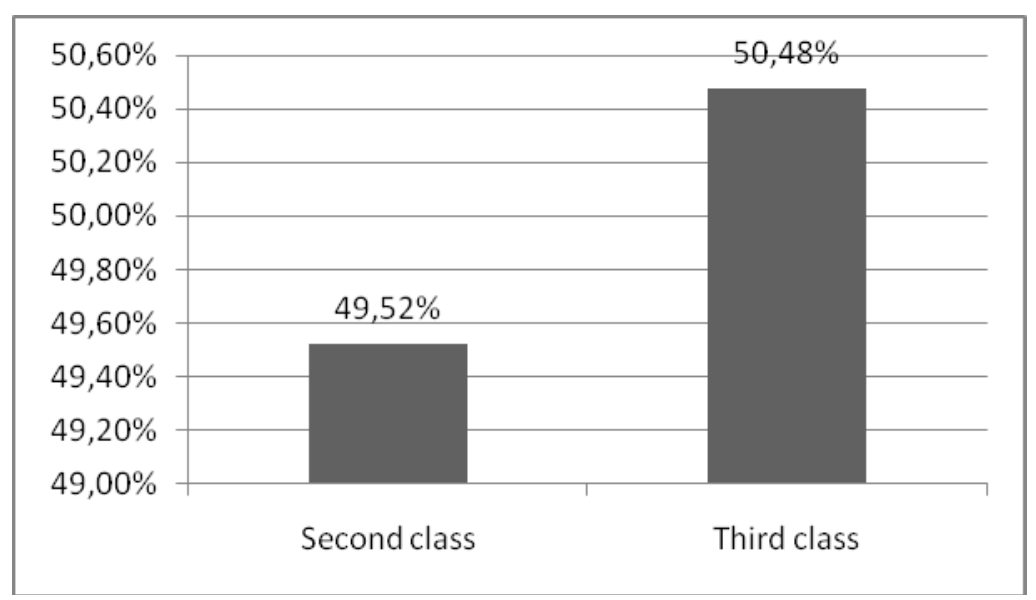

Figure 3. Which Class of The High School Do You Attend?

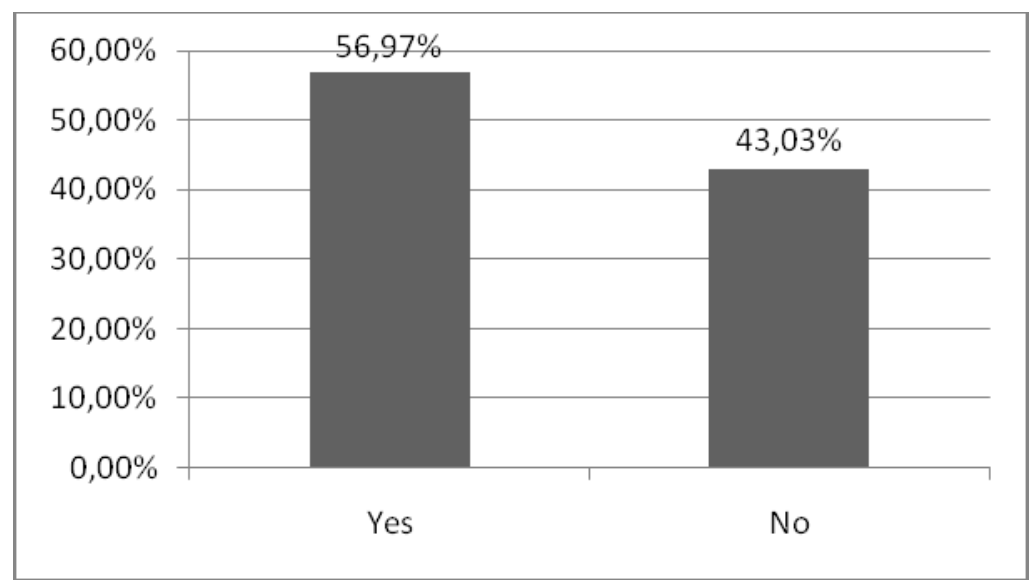

Figure 4. Are You Interested in Arts?

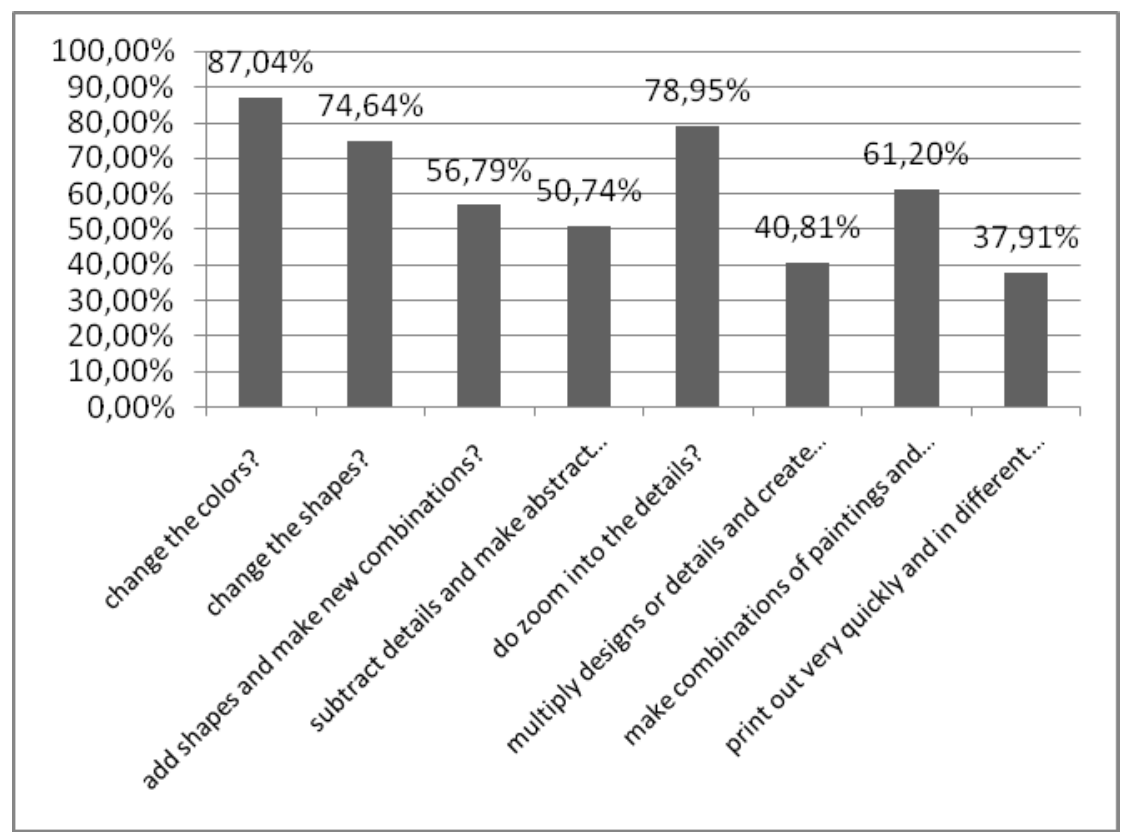

Figure 5. You Know How to Use the Computer to... 


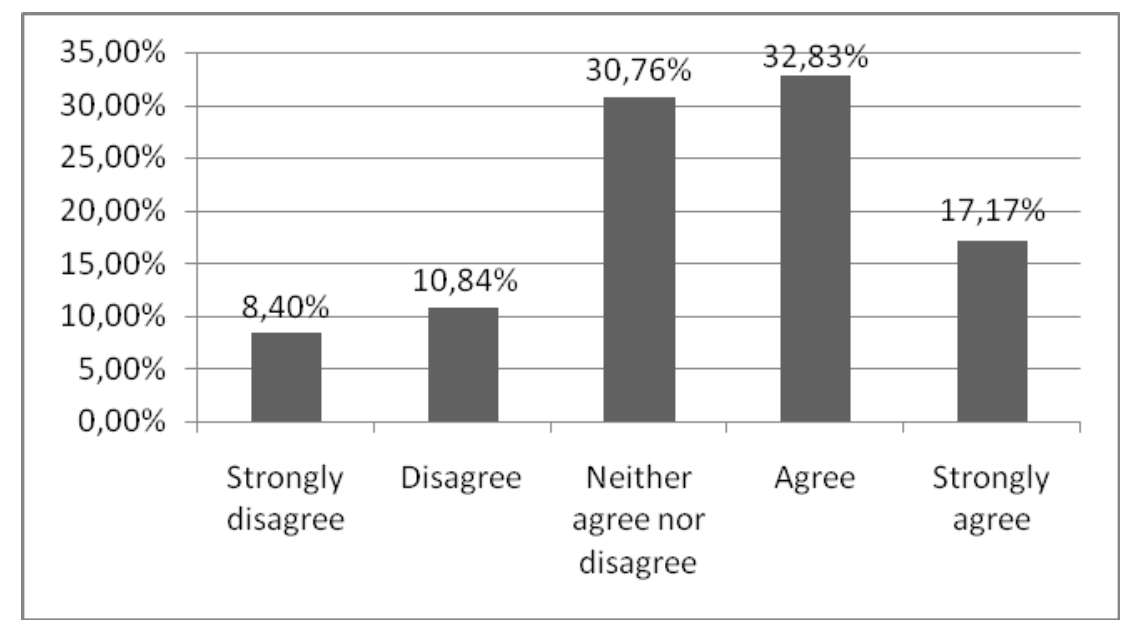

Figure 6. Is Art influenced by Technology Today?

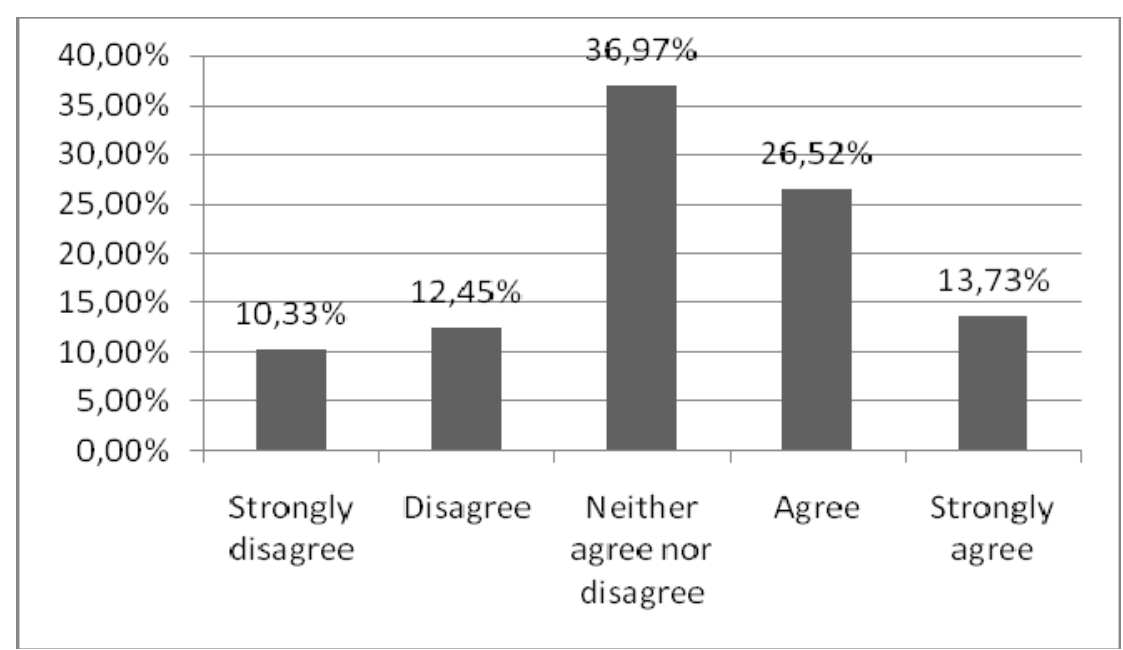

Figure 7. Is It Good for A Modern Artist to Use the Tools of Technology When Creating a Project?

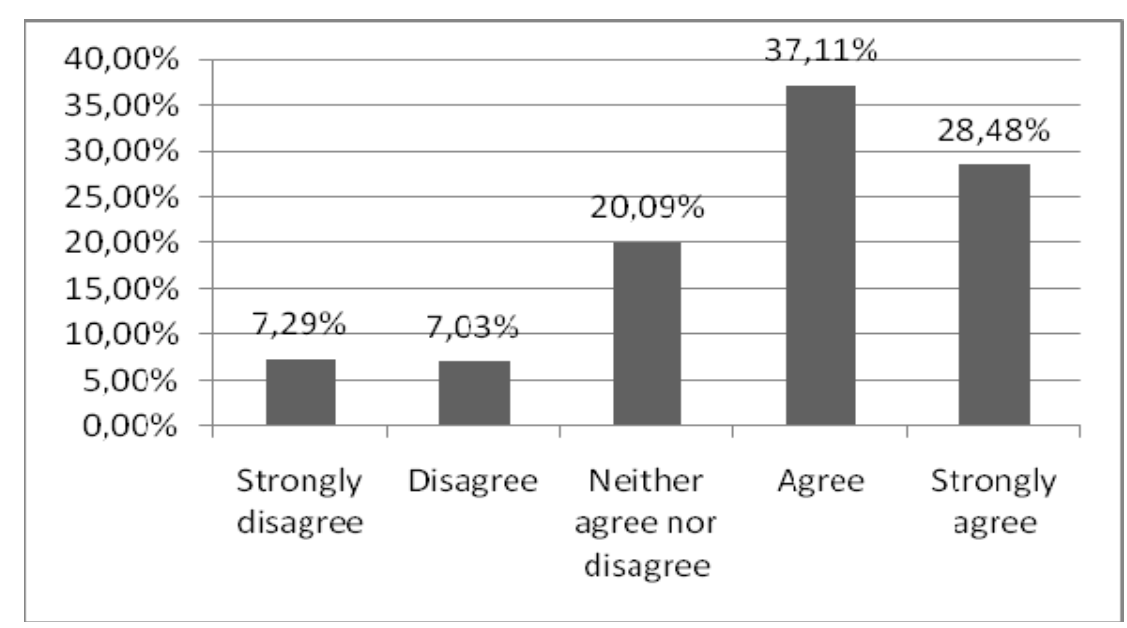

Figure 8. Has Technology Helped in the Creation of New Forms of Art? 


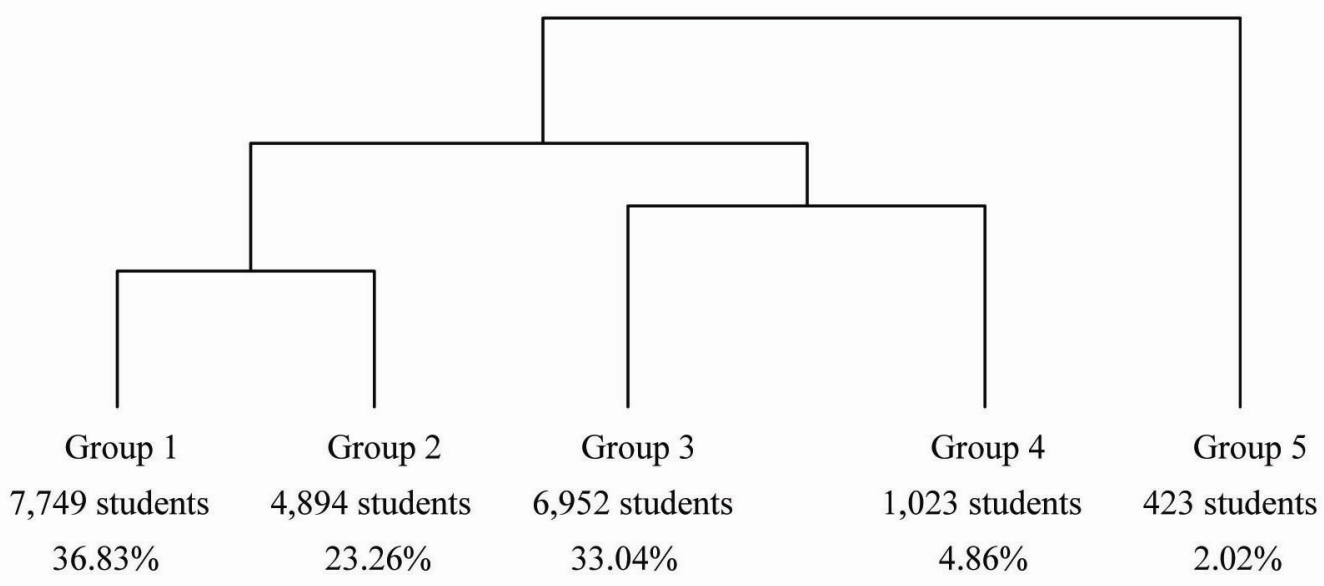

Figure 9. The Classification Chart

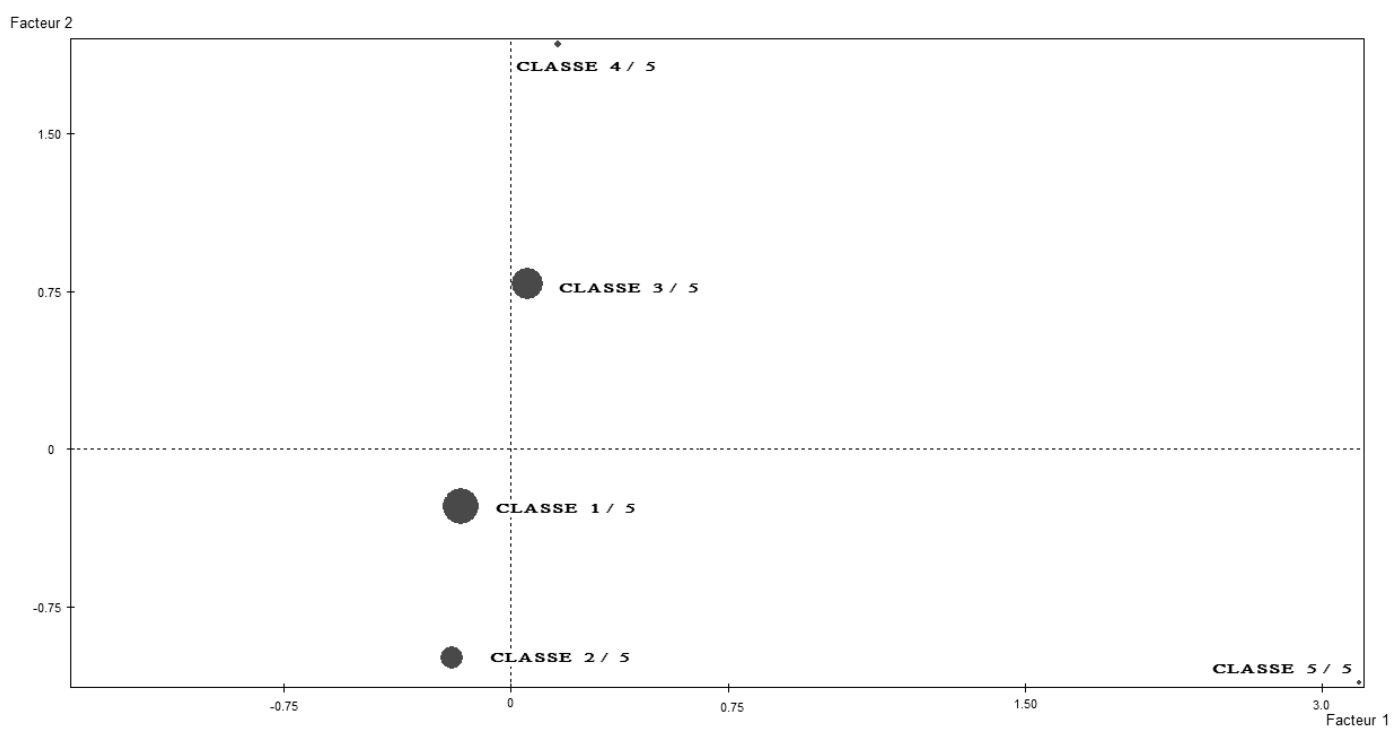

Figure 10. Correspondence Analysis 